In this survey, I shall contact various officials and consultants within the departments of education in the provinces. It is essential, though, that I have the independent and personal views of teachers. Therefore if you are involved in teaching (especially science) in the elementary or secondary schools, and/or if you have strong views or novel ideas on the subject, I would appreciate hearing from you. My address until July: Institute of Astronomy, University of Cambridge, Madingley Road, Cambridge, England. My address after July: Department of Astronomy, University of Toronto, Toronto M5S 1A7, Ontario, Canada.

JOHN R. PERCY

Associate Professor

David Dunlap Observatory

\title{
Notes from Newfoundland
}

Our annual meeting was held in October, resulting in the following election of officers: President, Dora Russell; Vice-president, Randell Dodge; Secretary, Bill Hurley; Treasurer, Dr. Peter Lockwood.

In November, we had a talk on UFO's, led by Garry Dymond. The subject was argued backwards, forwards and spacewards, but in spite of all efforts, we failed to solve the problem. Nonetheless, it provided an entertaining evening.

In December, we produced our usual Star of Bethlehem program in our little 24seater planetarium.

One project we have under way is worthy of mention, and may perhaps be emulated by some other centres.

George Draskoy, our Park Interpretation Supervisor, suggested we might plan a pamphlet for park use, showing a map of the summer skies and containing some general information. This we have completed, and the pamphlet ought shortly to be off the press. We hope to follow up the good work next summer by bringing our telescopes out to one of the parks some clear night. If this works out well, we shall do more of this sort of thing.

DORA RUSSELL

President, St. John's Centre

\section{NFGAAA Meets in Hamilton}

On Saturday, November 4, amateur astronomers from Southern Ontario and Western New York gathered in Hamilton for the Fall Meeting of the Niagara Frontier Council of Amateur Astronomical Associations. After a very short business session, five very interesting presentations were heard.

Martin Connors, from the London Centre, spoke briefly about his trip to the Canadian Rocket Range at Churchill, Man. Martin was there to measure changes in our ionosphere, and had many interesting remarks to make about our Far North.

Hamilton Centre's representative on the speakers list was Norman Green who spoke about "Planetariums, Past and Present". He traced the development of the planetarium from ancient star globes to orreries, to the modern million dollar "Theatre of the Stars".

Joe Italiano spoke briefly about the Summer Seminar of the NFCAAA held at Syracuse last July. This is a "camp-out" astronomical meeting for members of the NFCAAA.

An invited guest at the meeting was Dr. Tom Bolton of the David Dunlap Observatory. His topic was "Black Holes". Dr. Bolton traced the development of the theory of black holes and showed how astronomers were trying to develop techniques for observing these. One startling statement was that our entire Universe may be a black hole, since the observable Universe fits the theoretical model, both in observed radius and in the density of matter! 